\title{
The Impact of Work Stress on Job Satisfaction of Employees at Can Tho Radio and Television Station
}

\author{
Vo Thi Diem Thuy ${ }^{1}$, Nguyen Quoc Nghi ${ }^{2}$ \\ ${ }^{1}$ FPT Executive MBA Program, FPT University, ${ }^{2}$ Can Tho University, Vietnam \\ Corresponding Author: Nguyen Quoc Nghi
}

DOI: https://doi.org/10.52403/ijrr.20220127

\begin{abstract}
The study aims to demonstrate the influence of work stress on job satisfaction of employees at Can Tho Radio and Television (TV) Station. Research data were collected from 140 employees working at the Radio and TV Station of Can Tho City. Applying the structural equation modeling, the research has pointed out factors forming work stress. They include work overload, pressure from the manager, income pressure, workplace relationships, and working conditions. When work stress forms, it negatively impacts the job satisfaction of the staff at Can Tho Radio and TV Station.
\end{abstract}

Keywords: work stress, satisfaction, employee, Can Tho Radio and Television Station

\section{PROBLEM STATEMENT}

In the context of the Covid-19 epidemic, employees face many risks and challenges in terms of job stability and personal health. Therefore, work stress appears more often, which is a sign of a decline in the quality of life. Stress is no longer a strange term in modern life. According to Selye (1956), stress is all lifeincluded wear and tear. Stress not only reduces life quality but also leads to many diseases. Every field of career has its peculiarities and potential job stress risks. According to Vansell et al. (1981), work stress arises when employees perform tasks that require certain independence and authority to achieve the best performance, while the organization does offer them enough power. Researches by Shahu and
Gole (2008), Karunanithy and Ponnampalam (2013), Ali et al. (2014) show that work stress will reduce job satisfaction and affect employees' work results.

Can Tho Radio and TV Station is responsible for transmitting the State's guidelines, policies, and laws, and orienting the public opinion. Due to the nature of their work, most staff working at Can Tho Radio and TV Station are reporters, editors, and technicians. The staff has to ensure to report the information timely, maintain the pace of the program production process. Busyness and work pressure make employees feel stressed at work.

For sustainable development, one of the top essentials is a team of qualified, mentally and physically healthy human resources to devote themselves to the job. The Radio-TV Station regularly develops management methods. This motivates employees to be enthusiastic and creative at work so that they dedicate themselves to work. Observing, recognizing, and helping employees reduce stress at work is necessary, thereby improving employee satisfaction and work results (Nghi et al., 2020). Therefore, the study "The impact of work stress on job satisfaction of employees at Can Tho Radio and TV Station" is essential for implementation. 


\section{THEORETICAL FRAMEWORK AND RESEARCH MODEL 2.1 Theoretical framework Work stress}

Work stress occurs when employees need the independence or power to perform tasks and achieve the best results, but they do not receive enough authority from the organization (Vansell et al., 1981). According to Luthans (1995), work stress is a chronic disease that negatively affects personal productivity. Houtman (2005) has argued that job stress is a combination of reactions created if employees' skills and abilities cannot cope with their job requirements. According to the World Health Organization (WHO), job stress arises if job requirements and pressures exceed workers' knowledge and abilities. This requires workers to have the ability to deal with difficulties at work.

\section{Job satisfaction}

Job satisfaction is a reflection of the employees' love for work, that is, employees' feelings or emotions towards their job (Luddy, 2005). Job satisfaction is the content to which employees love their jobs, which is an attitude based on positive or negative perceptions about the job and working environment (Ellickson and Logsdon, 2001). As presented by Kusku (2003), the job satisfaction of employees reflects the extent to which their needs and demands are met. According to Yeoh (2007), job satisfaction is measured by employees' feelings about job characteristics, working conditions, superiors, colleagues, income, benefits, and promotion.

\subsection{Research model}

Based on the literature review, five common factors that shape employee work stress include work overload, superiors' pressure, income pressure, workplace relationships, and working conditions.

Work overload: Too much workload or tasks that are not suitable for employees' strengths may easily lead to work stress. Many studies have shown that work overload is one of the main causes of job stress (Bashir and Ramay, 2010; Sharma and Devi, 2011; Karunanithy and Ponnampalam, 2013; Ali et al., 2014; Nghi et al., 2020).

Pressure from superiors: One of the causes of work stress is that employees do not receive support from their managers. Unfair evaluation or disregarding can also lead to stress at work (Dahmodharan and Arumugasamy, 2011; Sharma and Devi, 2011; Loan, 2017; Nghi et al., 2020).

Income pressure: Income is the main source of living expenses. Income includes salary and welfares corresponding to the employees' job position. If employees find salary and welfare policy unequal, or the income is too low to cover the expenses, employees may feel stressed (Karunanithy and Ponnampalam, 2013; Ali et al., 2014; Nghi et al., 2020).

Relationships: Workplace relationships include personal interactions between employees and their colleagues, or managers. Several studies have demonstrated that negative relationships have an important impact on the formation of job stress (Karunanithy and Ponnampalam, 2013; Jou et al., 2013; Loan, 2017; Nghi et al., 2020).

Working conditions: The workplace environment includes working space, facilities, equipment, and working regulations. A comfortable working environment reduces psychological pressure and stress. In contrast, an unfavorable working environment is a crucial factor in the formation of job stress (Karunanithy and Ponnampalam, 2013; Bashir and Ramay, 2010; Loan, 2017).

The study proposes five factors that form the work stress of the staff working at Can Tho Radio and TV Station, including work overload, pressure from superiors, income pressure, workplace relationships, and working conditions.

The relationship between job stress and job satisfaction: According to Adams (1980), job stress leads to job dissatisfaction 
Vo Thi Diem Thuy et.al. The impact of work stress on job satisfaction of employees at Can Tho radio and television station.

and poor motivation, thereby decreasing commitment to the organization. Research by Nghi et al. (2020) shows that a high level of work stress causes a low level of job satisfaction. Studies of Cummins (1990), Igharia and Greenhaus (1992), Iqbal and Waseem (2012) emphasize that people who suffer from work stress are dissatisfied with their jobs and tend to leave the organization.
Therefore, the study hypothesizes "Work stress negatively affects the job satisfaction of employees at Can Tho and TV Station."

Based on the literature review and research hypothesis, a research model on the influence of work stress on job satisfaction of employees at Can Tho Radio and TV Station is proposed below.

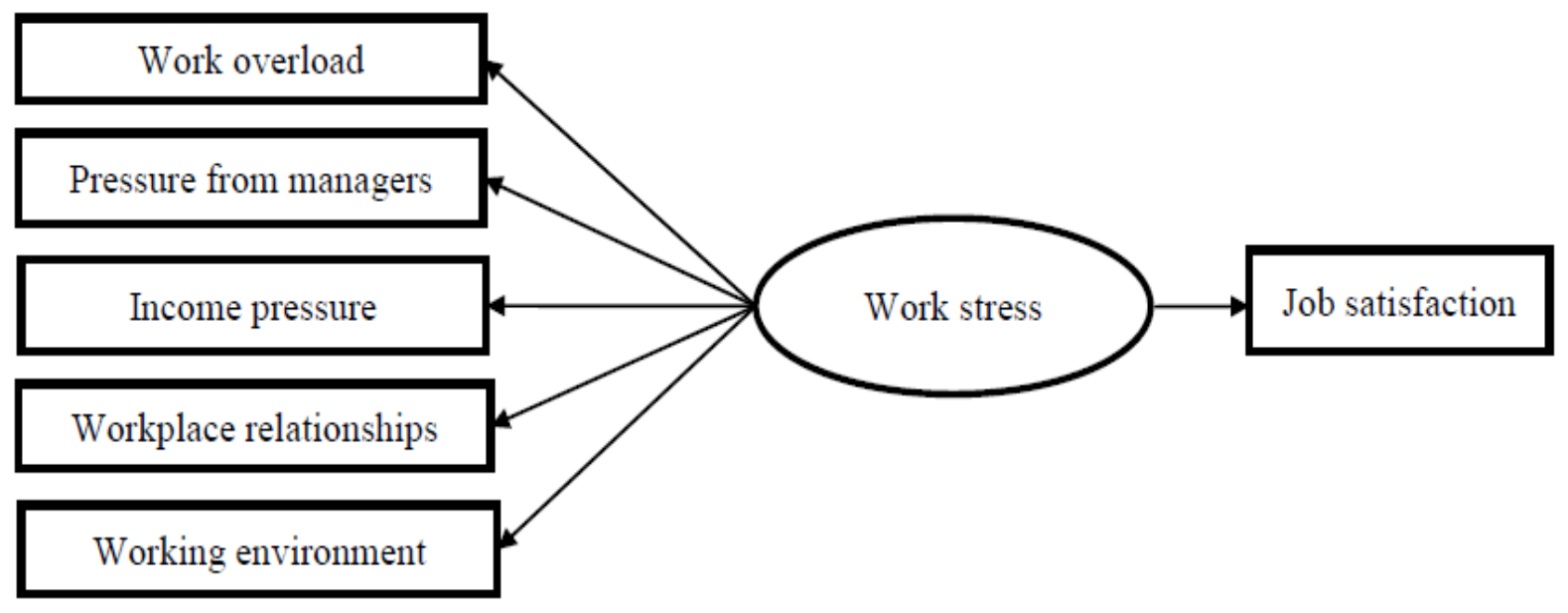

Figure 1: Proposed research model

Table 1: Interpretation of observed variables in the research model

\begin{tabular}{|c|c|c|c|}
\hline Factor & $\begin{array}{c}\text { Observed variables } \\
\end{array}$ & Scale & $\begin{array}{l}\text { Reference resources } \\
\end{array}$ \\
\hline \multirow[t]{4}{*}{ Work overload (WO) } & WO1: I feel pressured by the assigned target. & $\begin{array}{l}\text { Likert } \\
1-5\end{array}$ & \multirow[t]{4}{*}{$\begin{array}{l}\text { Karunanithy and Ponnampalam (2013), Ali et } \\
\text { al. (2014), Nghi et al. (2020) }\end{array}$} \\
\hline & WO2: My work is always backlogged. & $\begin{array}{l}\text { Likert } \\
1-5\end{array}$ & \\
\hline & WO3: My job is risky. & $\begin{array}{l}\text { Likert } \\
1-5\end{array}$ & \\
\hline & WO4: I feel overwhelmed with my workload & $\begin{array}{l}\text { Likert } \\
1-5\end{array}$ & \\
\hline \multirow[t]{4}{*}{$\begin{array}{l}\text { Pressure from } \\
\text { managers (PM) }\end{array}$} & $\begin{array}{l}\text { PM1: Managers do not understand employees' } \\
\text { workload. }\end{array}$ & $\begin{array}{l}\text { Likert } \\
1-5\end{array}$ & \multirow[t]{4}{*}{$\begin{array}{l}\text { Sharma and Devi (2011), Loan (2017), Nghi et } \\
\text { al. (2020) }\end{array}$} \\
\hline & $\begin{array}{l}\text { PM2: Managers put pressure on employees to } \\
\text { achieve high efficiency. }\end{array}$ & $\begin{array}{l}\text { Likert } \\
1-5\end{array}$ & \\
\hline & $\begin{array}{l}\text { PM3: Managers do not support when employees } \\
\text { encounter difficulties at work. }\end{array}$ & $\begin{array}{l}\text { Likert } \\
1-5\end{array}$ & \\
\hline & $\begin{array}{l}\text { PM4: Managers unfairly evaluate employees' } \\
\text { performance. }\end{array}$ & $\begin{array}{l}\text { Likert } \\
1-5\end{array}$ & \\
\hline \multirow[t]{3}{*}{ Income pressure (IP) } & $\begin{array}{l}\text { IP1: The salary is not commensurate with the job } \\
\text { performance. }\end{array}$ & $\begin{array}{l}\text { Likert } \\
1-5\end{array}$ & \multirow[t]{3}{*}{$\begin{array}{l}\text { Karunanithy and Ponnampalam (2013), Ali et } \\
\text { al. (2014), Nghi et al. (2020) }\end{array}$} \\
\hline & IP2: Unreasonable reward policy. & $\begin{array}{l}\text { Likert } \\
1-5\end{array}$ & \\
\hline & IP3: Unreasonable welfare policy. & $\begin{array}{l}\text { Likert } \\
1-5\end{array}$ & \\
\hline \multirow[t]{4}{*}{$\begin{array}{c}\text { Workplace } \\
\text { relationship (WR) }\end{array}$} & WR1: Colleagues are not friendly. & $\begin{array}{l}\text { Likert } \\
1-5\end{array}$ & \multirow[t]{4}{*}{$\begin{array}{l}\text { Karunanithy and Ponnampalam (2013), Jou et } \\
\text { al. (2013), Loan (2017) }\end{array}$} \\
\hline & WR2: Frequent conflicts with colleagues. & $\begin{array}{l}\text { Likert } \\
1-5\end{array}$ & \\
\hline & WR3: Colleagues do not support at work. & $\begin{array}{l}\text { Likert } \\
1-5\end{array}$ & \\
\hline & WR4: It is hard to share with colleagues. & $\begin{array}{l}\text { Likert } \\
1-5\end{array}$ & \\
\hline \multirow[t]{3}{*}{$\begin{array}{l}\text { Working environment } \\
\text { (WE) }\end{array}$} & WE1: The workplace is not comfortable. & $\begin{array}{l}\text { Likert } \\
1-5\end{array}$ & \multirow[t]{3}{*}{$\begin{array}{l}\text { Bashir and Ramay (2010), Loan (2017), Nghi } \\
\text { et al. (2020) }\end{array}$} \\
\hline & WE2: Not having enough equipment to do the job. & $\begin{array}{l}\text { Likert } \\
1-5\end{array}$ & \\
\hline & $\begin{array}{l}\text { WE3: Uncomfortable with work rules (dress code, } \\
\text { working time) }\end{array}$ & $\begin{array}{l}\text { Likert } \\
1-5\end{array}$ & \\
\hline
\end{tabular}


Vo Thi Diem Thuy et.al. The impact of work stress on job satisfaction of employees at Can Tho radio and television station.

\begin{tabular}{|c|c|c|c|}
\hline \multicolumn{4}{|c|}{ Table 1 Continued... } \\
\hline \multirow[t]{5}{*}{ Job satisfaction (JS) } & JS1: Managers always share and encourage staff. & $\begin{array}{l}\text { Likert } \\
1-5\end{array}$ & \multirow[t]{5}{*}{$\begin{array}{l}\text { Ellickson and Logsdon (2001), Kusku (2003), } \\
\text { Yeoh (2007) }\end{array}$} \\
\hline & JS2: Good salary, bonus, and welfare policies. & $\begin{array}{l}\text { Likert } \\
1-5\end{array}$ & \\
\hline & JS3: Active working environment. & $\begin{array}{l}\text { Likert } \\
1-5\end{array}$ & \\
\hline & $\begin{array}{l}\text { JS4: Satisfied with the training and promotion } \\
\text { policy. }\end{array}$ & $\begin{array}{l}\text { Likert } \\
1-5\end{array}$ & \\
\hline & JS5: Satisfied with working conditions. & $\begin{array}{l}\text { Likert } \\
1-5\end{array}$ & \\
\hline
\end{tabular}

\subsection{Analytical method}

The study applied structural equation modeling (SEM) to test the research hypotheses. This method requires a large sample size because it is based on sample distribution theory (Raykov and Widaman, 1995). To reach the high reliability in the SEM model, the sample size from 100 to 200 is satisfactory (Hoyle, 1995). The study surveyed 140 employees working at the Can Tho City Radio and TV Station by convenient sampling. Hence, the sample size meets the requirements, ensuring the reliability of the model test.

\section{RESEARCH RESULTS AND DISCUSSION}

\subsection{Evaluate the reliability of scales}

To test the research hypotheses, the analyses are performed in the following order: Step 1: Test the reliability of the scale. Step 2: Exploratory factor analysis
(EFA). Step 3: Confirmatory factor analysis (CFA). Step 4: Structural equation modeling (SEM).

\section{Step 1: Test the reliability of scales}

Based on the results in table 2, all scales of work stress and job satisfaction have Cronbach's Alpha values greater than 0.7. This shows that the scales have high reliability (Nunnally, 1978; Peterson, 1994; Slater, 1995). The Cronbach's Alpha values of each scale are as follows, "Work overload" and "Pressure from managers" both reach 0.826, "Income pressure" reaches 0.742 , "Working conditions" reaches 0.838 , "Workplace relationships" has a value of 0.850 , and "Job satisfaction" has a value of 0.765 . Item-total correlation coefficients are all greater than the limit of 0.3 . It proves that the scales are reliable and 23 observed variables are used for the next EFA.

Table 2: Scale reliability test result

\begin{tabular}{|c|l|c|c|c|}
\hline No. & \multicolumn{1}{|c|}{ Scale } & Number of observations & Cronbach's Alpha & Min corrected item-total correlation \\
\hline 1 & Work overload & 4 & 0.826 & 0.617 \\
\hline 2 & Pressure from managers & 4 & 0.826 & 0.636 \\
\hline 3 & Income pressure & 3 & 0.742 & 0.489 \\
\hline 4 & Workplace relationships & 4 & 0.850 & 0.648 \\
\hline 5 & Working environment & 3 & 0.838 & 0.658 \\
\hline 6 & Job satisfaction & 5 & 0.765 & 0.479 \\
\hline \multicolumn{2}{|c|}{ Source: Survey data, 2021 } \\
\hline
\end{tabular}

Step 2: Exploratory Factor Analysis (EFA)

Table 3: Factors created from the EFA result

\begin{tabular}{|c|l|l|}
\hline Sign & Observed variables & Factor \\
\hline $\mathrm{F}_{1}$ & 4 variables: WR1, WR2, WR3, WR4 & $\begin{array}{l}\text { Workplace } \\
\text { relationships }\end{array}$ \\
\hline $\mathrm{F}_{2}$ & 4 variables: WO1, WO2, WO3, WO4 & Work overload \\
\hline $\mathrm{F}_{3}$ & 4 variables: PM1, PM2, PM3, PM4 & $\begin{array}{l}\text { Pressure from } \\
\text { managers }\end{array}$ \\
\hline $\mathrm{F}_{4}$ & 5 variables: JS1, JS2, JS3, JS4, JS5 & Job satisfaction \\
\hline $\mathrm{F}_{5}$ & 3 variables: WE1, WE2, WE3 & $\begin{array}{l}\text { Working } \\
\text { environment }\end{array}$ \\
\hline $\mathrm{F}_{6}$ & 3 variables: TN1, TN2, TN3 & Income pressure \\
\hline \multicolumn{3}{|c|}{ Source: Survey data, 2021 } \\
\hline
\end{tabular}

The EFA results for the component scales in the model achieved the following values: (1) Reliability of observed variables (Factor loading) $>0.5$. (2) Suitability test of the model $(0.5<\mathrm{KMO}=0.812<1.0)$. (3) Bartlett's test on correlation of observed variables (Sig. $=0.00<0.05$ ). (4) Total variance explained $=55.62 \%>50 \%$. Therefore, the observed variables achieved discriminant and convergent validity (Hair et al., 1998). There are 6 factors created from 23 observed variables, there is no 
Vo Thi Diem Thuy et.al. The impact of work stress on job satisfaction of employees at Can Tho radio and television station.

variable disturbance, so the names of factors remain the same.

\section{Step 3: Confirmatory Factor Analysis (CFA)}

The above six factors are included in the CFA. The result shows that the following values are guaranteed: Chisquare $/ \mathrm{df}=1,190<2$ with $\mathrm{P}=0.029 \leq 0.05$. The TLI and CFI indictors reach 0.960 and 0.966, which are all greater than 0.9. RMSEA $=0.037<0.08$. This proves the model fits the market data. The standardized regression weights of the scale are all greater than 0.5 and the unstandardized regression weights are statistically significant. The model achieves convergent validity. Besides, the correlation coefficients between the factors are all less than 1 with standard deviations less than 0.05. Therefore, the research model reaches discriminant validity. The results of composite reliability (Pc) and average variance extracted $(\mathrm{Pvc})$ in table 4 show that the Pc and Pvc values are satisfactory (Fornell et al. Larcker, 1981; Fraering and Minor, 2006). Thus, all the factors in the model are suitable for the next step of SEM.

Table 4: Test the scales in the research model

\begin{tabular}{|l|r|r|r|r|}
\hline \multicolumn{1}{|c|}{ Factor } & Number of observed variables & Composite reliability $\mathbf{P}_{\mathbf{c}}$ & ${\text { Average variance explained } \mathbf{P}_{\mathbf{v c}}}^{\text {Value }^{*}}$ \\
\hline Work overload & 4 & 0.82 & 0.54 \\
\hline Pressure from managers & 4 & 0.83 & 0.54 \\
\hline Income pressure & 3 & 0.75 & 0.51 \\
\hline Workplace relationships & 4 & 0.85 & 0.59 \\
\hline Working environment & 3 & 0.84 & 0.65 \\
\hline Job satisfaction & 5 & 0.77 & 0.50 \\
\hline
\end{tabular}

\subsection{Test research hypotheses by structural equation modeling (SEM)}

The method of SEM is used to test the research hypotheses. The results of the analysis are in table 5.

Table 5: Evaluate the relationship between factors in the model

\begin{tabular}{|l|c|c|c|c|}
\hline \multicolumn{2}{|l|}{ Relationship } & Standardized estimated value & P-value \\
\hline Work overload & $<-$ & Work stress & 0.693 & $* * *$ \\
\hline Pressure from managers & $<-$ & Work stress & 0.837 & $* * *$ \\
\hline Income pressure & $<-$ & Work stress & 0.376 & 0.001 \\
\hline Workplace relationships & $<-$ & Work stress & 0.741 & $* * *$ \\
\hline Working environment & $<-$ & Work stress & 0.321 & 0.003 \\
\hline Job satisfaction & $<-\mid$ Work stress & -0.230 & 0.043 \\
\hline
\end{tabular}

Based on the test results in table 5, work overload, managers' pressure, income pressure, working environment, and workplace relationships are all statistically significant at a level of $5 \%$ and get positive standardized estimated values. This proves that these five elements cause work stress for the staff at Can Tho Radio and TV Station. Among these factors, pressure from managers is the most influencing factor to employees' job stress because of its highest standardized value. Simultaneously, this study has demonstrated that work stress negatively affects the job satisfaction of employees. This result is similar to the findings of Cummins (1990), Igbaria and Greenhaus (1992), Iqbal and Waseem
(2012), Nghi et al. (2020). To sum up, the higher the level of work stress, the lower the job satisfaction. This implies that reducing stress at work is an effective solution to improve job satisfaction of employees at Can Tho Radio and TV Station.

\section{CONCLUSION}

The study has indicated the factors that cause work stress of the staff working at Can Tho Radio and TV Station, including work overload, superior' pressure, income pressure, relationships, and the working environment. In which, the pressure from managers puts the most influence on employees' work stress. The work stress that occurs may negatively affect the 
satisfaction of employees. It concludes that work stress is a very essential issue that the manager board of Can Tho Radio and TV Station should focus on to improve the job satisfaction of employees.

\section{Acknowledgement: None}

\section{Conflict of Interest: None}

\section{Source of Funding: None}

\section{REFERENCES}

1. Adams, J. D. (1980). On Consuming Human Resources: Perspectives on the Management of Stress. In Adams, J. D. (Ed.). Understanding and Managing Stress: A book of readings. San Diego, CA: University Associates Inc.

2. Ali, W. U., Raheem, A. R., Nawaz, A., \& Imamuddin, K. (2014). Impact of stress on job performance: An empirical study of the employees of private sector universities of Karachi, Pakistan. Research Journal of Management Sciences, 3(7), 14-17.

3. Bashir, U., \& Ismail Ramay, M. (2010). Impact of Stress on Employees Job Performance A Study on Banking Sector of Pakistan. International Journal of Marketing Studies, 2(1), 122-126.

4. Cummins, R. C. (1990). Job stress and the buffering effort of supervisory support. Group and Organizational Studies, 15(1), 92-104.

5. Dahmodharan, K., \& Arumugasamy, G. (2011). Effect of occupational stress on executives' leadership styles. Public policy and administration research, 1(4), 224-573.

6. Ellickson, M. C., \& Logsdon, K. (2001). Determinants of job satisfaction of municipal government employees. State and Local Government Review, 33(3), 173-184.

7. Fornell, C., \& Larcker, D. F. (1981). Evaluating structural equation models with unobservable variables and measurement error. Journal of marketing research, 18(1), 39-50.

8. Fraering, M., \& Minor, M. S. (2006). Sense of community: an exploratory study of US consumers of financial services. International Journal of Bank Marketing, 24(5), 284-306.

9. Hair, J. F., Tatham, R. L., Anderson, R. E., \& Black, W. (1998). Multivariate Data
Analysis (5th ed.). New Jersey: PrenticeHall, Inc.

10. Hoyle, R. H. (1995). Structural equation modeling: Concepts, issues, and applications. Oaks, CA: Sage.

11. Igbaria, M., \& Greenhaus, J. H. (1992). Determinants of MIS employees' turnover intentions: A structural equation model. Communications of the ACM, 35(2), 34-49.

12. Iqbal, M., \& Waseem, M. A. (2012). Impact of job stress on job satisfaction among air traffic controllers of civil aviation authority: An empirical study from Pakistan. International journal of human resource studies, 2(2), 53.

13. Irene Houtman, K. J. (2005). Raising awareness of stress at work in developing countries. Retrieved December 21, 2010.

14. Jou, R. C., Kuo, C. W., \& Tang, M. L. (2013). A study of job stress and the turnover tendency among air traffic controllers: The mediating effects of job satisfaction. Transportation research part E: logistics and transportation review, 57, 95104.

15. Karunanithy, K., \& Ponnampalam, A. (2013). A study on the effect of stress on the performance of employees in Commercial Bank of Ceylon in the Eastern Province. European Journal of Business and Management, 5(27), 87-95.

16. Kusku, F (2003). Employee satisfaction in higher education: the case of academic and administrative staff in Turkey. Career Development International, 8(7), 347-356.

17. Loan, T. T. K. (2017). Survey on factors affecting occupational stress of employees at Tan Phu District Hospital. Master thesis. University of Economics Ho Chi Minh City.

18. Luddy, N. (2005). Job satisfaction amongst employees at a public health institution in the Western Cape (Doctoral dissertation, University of the Western Cape).

19. Luthans, F. (1995). Organizational Behaviour (7th ed.). Singapore: Mcgraw Hill Book Company.

20. Nunnally, J. (1978). Psychometric Theory. New York: McGraw-Hill.

21. Nghi, N. Q., Loc, H. T. H., \& Long, N. D. H. (2020). The impact of occupational stress on job satisfaction and job performance of banking credit officers. Management Science Letters, 10(16), 3891-3898. 
Vo Thi Diem Thuy et.al. The impact of work stress on job satisfaction of employees at Can Tho radio and television station.

22. Peterson, R. A. (1994). A meta-analysis of Cronbach's coefficient alpha. Journal of consumer research, 21(2), 381-391.

23. Raykov, T., \& Widaman, K. F. (1995). Issues in applied structural equation modeling research. Structural Equation Modeling: A Multidisciplinary Journal, 2(4), 289-318.

24. Selye, H. (1956). The stress of life. New York, NY: McGraw-Hill.

25. Shahu, R., \& Gole, S. V. (2008). Effect of job stress and job satisfaction on performance: An empirical study. AIMS International Journal of Management, 2(3), 237-246.

26. Sharma, J., \& Devi, A. (2011). Role stress among employees: An empirical study of commercial banks. Gurukul business review, 7(1), 53-61.
27. Slater, S. F. (1995). Issues in conducting marketing strategy research. Journal of Strategic Marketing, 3(4), 257-270.

28. Van Sell, M., Brief, A. P., \& Schuler, R. S. (1981). Role conflict and role ambiguity: Integration of the literature and directions for future research. Human Relations, 34(1), 43-71.

29. Yeoh, T. E. S. (2007). The Facet Satisfaction Scale: Enhancing the measurement of job satisfaction. The University of North Texas.

How to cite this article: Vo Thi Diem Thuy, Nguyen Quoc Nghi. The impact of work stress on job satisfaction of employees at Can Tho radio and television station. International Journal of Research and Review. 2022; 9(1): 209-215. DOI: https://doi.org/10.52403/ijrr. 20220127 